\title{
TROPICAL ORCHIDS IN THE NORTH, MONTRÉAL BOTANICAL GARDEN, QUÉBEC, CANADA
}

\author{
LISE GOBEILLE \\ 'Curator Orchid Collection, 4101 Sherbrooke East, Montréal, Québec, H1X 2B2, Canada \\ lisegobeille@ville.montreal.qc.ca
}

KEY WORDS: orchid collection, history, conservation, Botanical Garden

The Montréal Botanical Garden was founded, in 1931 , by the remarkable botanist and scientist, catholic brother Marie Victorin. Since its foundation the garden has three missions : conservation, education and research. Certainly 76 years old is still young for a botanical garden, but it has accomplished a maturity and dynamism that is admired by many. The tropical collections are presented to the public by family and theme in ten public greenhouses. Behind the scene, more than 40 greenhouses serve for conservation of our collections, for production and for research. Situated on 75 hectares, 27 thematic gardens present the different collections while three gardens have a cultural vocation: the Chinese Garden, the Japanese Garden and the American Indian Garden. A total of 22,000 taxons are presented in our collections.

Considering its size, the richness of its collections, the number of employees and the number of visitors $(1,000,000 /$ year$)$, the Montréal Botanical Garden ranks as one of the five largest in the world.

Henry Teuscher, co-founder of the Montréal Botanical Garden, designed the garden and supervised its construction. He was appointed as curator in 1942, a position he occupied until his retirement in 1962. During this 20 year period he established the basis of the collections, particularly the orchid collection, for which he had a real passion. He wrote hundreds of articles for the American Orchid Society Bulletin under the title of 'Collector's Item', articles which were very much appreciated by collectors of species. Mr. Teuscher became more and more interested in taxonomy and collaborated with Leslie A. Garay, taxonomist botanist at Oakes Ames Herbarium at Harvard University in Boston, MA (U.S.A) Mr. Garay identified some new species from samples from the Botanical Garden collection and he named the genus Teuscheria in honour of Mr. Teuscher. Mr. Teuscher's contribution to the knowledge of orchids was the first and the most important in Eastern Canada.

Early in his career, in the years of 1940-1950, Mr. Teuscher established contacts with different botanical gardens recognized for their orchid collections and he solicited donations and exchanges. As a result of his efforts, the New York Botanical Gardens (Bronx, NYC, U.S.A), the Palmentengarten of Frankfort (Germany) and the National Botanical Garden of Dublin (Ireland) as well as many others contributed to the formation of the nucleus of our orchid collection. From 1945 to 1975 the development of our collection focused on South American species sent by two orchid hunters, J. Strobel of Cuenca, Ecuador and C.K. Horich of San Jose, Costa Rica. The specimens were often identified only by genus, sometimes simply as 'orchid number...'. However, they included information concerning habitat, altitude, color of flowers, collection site etc. This information facilitated both cultivation and identification of plants.

Pierre Bourque, director of the garden from 19801994, gave new life to the development of the collection and promoted its visibility by giving the collection its own public greenhouse. He was fascinated by orchids, their capacity to adapt and by their power of attraction. During his many overseas trips : Costa Rica, Ecuador, Hong Kong etc, he always had the orchid collection in mind and he brought back numerous species.

Also, we have had and continue to receive occasional donations from collectors who wish to assure the perpetuity of their collections by leaving their orchids to the Montréal Botanical Garden. These 
donations as well as exchanges with other institutions and with private collectors allow us to continue to enrich our collection. However, presently the majority of our acquisitions are plants we purchase from specialized producers who now offer a large variety of species.

For all of these reasons, our collection currently consists of $60 \%$ South American species, 30\% Asiatic species and $10 \%$ African species. The Montréal collection contains 270 genus, 1,440 species and 1,998 taxons, for a grand total of approximately 5,000 specimens (because we keep a minimum of two plants per taxon). We wish to maintain our historical emphasis on South America and to continue to add to the number of South American species in our collection.

To manage our collection, we use a data base named BGbase (Botanical Garden base) which permits us to keep information on each plant - collection site, geographic distribution, synonym, changes of nomenclature, etc. - enabling us to follow the evolution of each plant in our collection. With this data we can compile various detailed reports of the number of genus, number of species, number of IUCN plants, etc. This information is quickly and easily available to all horticultural personnel of the Botanical Garden. Our orchids are cultivated in three computer controlled greenhouses. The parameters of temperature, relative humidity, light levels and ventilation are precisely controlled, resulting in the exact climate necessary for their growth. The collection is maintained in four greenhouses, one of which is our 217 square meter public greenhouse where our visitors can appreciate orchids in flower 12 months of the year with new plants added each week.

Visitors have the choice of guided tours, where they can learn the basics of the orchid family, or they may visit the collection on their own. The flowering is particularly abundant between January and June. The three other greenhouses are production greenhouses. We have a 285 square meter hot greenhouse, a 354 square meter intermediate greenhouse, and a smaller 112 square meter cold greenhouse. During the last several years, we have experimented with mixtures of various materials : peat moss, sphagnum moss, rock wool, clay pellets, coconut bark, and the synthetic material epiweb. We test these various materials on different genus with the goal of finding the best mixtures which will perform well for our entire collection. We evaluate our mixtures over a two to three year period. During this time, we observe plant growth, measure $\mathrm{pH}$ and salinity levels and analyse soil and leaf samples. We also improved our fertilization methods. We work with ferti-irrigation of 100-150 ppm, using low phosphorous fertilizers, we use mainly nitrates, and we also add magnesium in the form of Epsom salt at each watering. Finally, one time per month, we add calcium and iron. We have observed an improvement in the growth and flowering of our plants and the number of CCM and CCE awarded for our plants in the past several years attest to this success. The Garden also has a laboratory where we practice in vitro propagation of rare, difficult or virus infected plants and the follow up of plants received in flasks.

At the Montreal Botanical Garden, we play an important de-facto role in conservation, considering the fact we have a collection of more than 5000 specimens, mainly species, many of which appear on the IUCN Red List. We plan to continue acquiring rare, vulnerable, or endangered species. We continue our mission of educating and raising public awareness through guided tours of our public orchid greenhouse, courses at the Botanical Garden school, and conferences offered to various horticultural groups.

In the future we would like to directly participate in ex-situ and/or in-situ conservation projects. We believe we have the knowledge, experience and facilities necessary to be valuable partners in orchid conservation efforts.

ACKNOWLEDGEMENTS. I would like to thank the Montréal Botanical Garden, who sent me here to present our orchid collection, thanks to the organizers who accepted my lecture and a special thanks to my husband Leo who translated my text from French to English.

\section{FURTHER READINGS}

Argo, B. 2003. Understanding $\mathrm{pH}$ management and plant nutrition. J. Intern. Phalaenopsis Alliance 12(4), 13(1-3).

Bouchard, A. 1998. Le Jardin botanique de Montréal: esquisse d'une histoire. Edition Fides, 111p.

Bulletin de la société d'animation du Jardin et de l'Institut botaniques 10(4): novembre-décembre. 
Quatre-Temps. 2006. Le Jardin botanique fête ses 75 ans! Quatre-Temps, La revue du Jardin botanique de Montréal 30(2-3).

Quatre-Temps. 1993. Les orchidées. Quatre-Temps, La revue du Jardin botanique de Montréal 17(1).

Stewart, J. 1995. Manual of orchids. Timber Press, Portland, $388 \mathrm{p}$.

Teuscher, H. 1940. Programme d'un jardin botanique idéal. Jardin botanique de Montréal, Montréal, 33 p.

Yin-Tang W. \& L.G. Lori. 1994. Medium and fertilizer affect the performance of Phalaenopsis orchids during two flowering cycles, HortScience 29(4): 269271.

Yin-Tung W. 1995. Medium and fertilization affect performance of potted Dendrobium and Phalaenopsis. Hort Techn. July- September.

Lise Gobeille has been in charge of the Orchid Collection at the Montréal Botanical Garden for the last 20 years. She has a degree from a Horticultural Technological Institute in La Pocatière, Québec. Regularly, she has been an invited speaker at various orchid societies. She also was on the editorial board of the 'Quatre-Temps', the magazine published by the Botanical Garden for five years and for two years, she wrote the quarterly 'Chronique Horticole' as well as numerous full length articles on orchids. Lise had attended numerous orchid conferences in Canada, U.S.A, Europe and Ecuador. 